\title{
Empirical Study on Preference Similarity Theory in China's Overseas Exhibitions
}

\author{
Airtok Lin ${ }^{1} \quad$ Grant G.L. Yang ${ }^{2 *}$
}

\begin{abstract}
As a part of the modern economic system, the exhibition industry has shown vigorous development and has attracted the general attention of all countries worldwide. The international exhibitions bring together many industries with wide influence, great development potential, and a high degree of industrial relevance. A large amount of information, technology, capital, and talents are gathered to promote the development and progress of commodity trade, industry development, technological and cultural exchanges, which play an important role in bringing considerable benefits to the global economy. Overseas exhibitions can provide excellent business opportunities for enterprises as an efficient marketing method, not only insincerity but also more access to potential customers. Based on the overseas exhibitions that China has participated in, this paper analyzes and proves the Preferences Similar Theories in China's participation in the Belt and Road and non-the Belt and Road countries. Results of this study may suggest the future layout of the global exhibition.
\end{abstract}

Keywords: Overseas Exhibition, Preference Similarity Theory, Economic Globalization

\section{Introduction}

\subsection{Present Situation of Exhibitions}

The modern exhibition is a collection of display and sales, which plans and organizes large-scale social activities of conference and exhibition. The Global Association of the Exhibition Industry (UFI) has expounded three main parts of the economic impacts of the exhibition: direct impacts, indirect impacts, and induced impacts. Direct impacts consist of the direct spending and jobs that are directly involved in planning and producing exhibitions, and for participants and exhibitors to travel to exhibitions, as well as another exhibitionrelated spending. Indirect impacts represent downstream supplier industry impacts, also referred to as supply chain impacts. For example, the facilities at which exhibitions occur require inputs such as energy and food ingredients. Also, many exhibition venues contract with specialized service providers, such as marketing, equipment upkeep, cleaning, technology support, accounting, and legal and financial services. Induced impacts occur as employees spend their wages and salaries in the broader economy. For example, hotel employees spend money on rent, transportation, food and beverage, and entertainment.

In 2018, approximately 32,000 exhibitions sold nearly 138 million net square meters (1.5 billion square feet) across more than 180 countries. Exhibitions generated nearly $€ 116.0$

\footnotetext{
${ }^{1}$ School of International Business, Xiamen University Tan Kah Kee College

2 Associate Professor of School of International Business, Xiamen University Tan Kah Kee College, grant@xujc.com*corresponding author

${ }^{3}$ This research is partially funded by the start-up fee for young teachers in Xiamen University Tan Kah Kee College ${ }^{\#}$ JG2018SRF08
} 
(\$136.9) billions of direct spending by visitors, exhibitors, and additional exhibitions related to expenditure. North America and Europe ranked first and second in direct spending, which represented $44 \%$ and $34 \%$ of total global direct spending in 2018, respectively (Figure 1). Exhibitions welcomed nearly 303 million visitors and 4.5 million exhibitors in 2018. Europe ranked first in total visitors, with 112.0 million visitors and 1.3 million exhibitors (Figure 2). North America followed with 91.2 million visitors and 1.6 million exhibitors (UFI, 2019).

With the rapid development of global economics and the huge economic benefits of international conventions and exhibitions, the convention and exhibition industry, as an important part of the modern economic system, is gradually receiving the attention of governments of various countries. Various countries have organized various large-scale international conventions and exhibitions. Under the trend of event internationalization, the expansion of the exhibition industry will usher in a new climax.
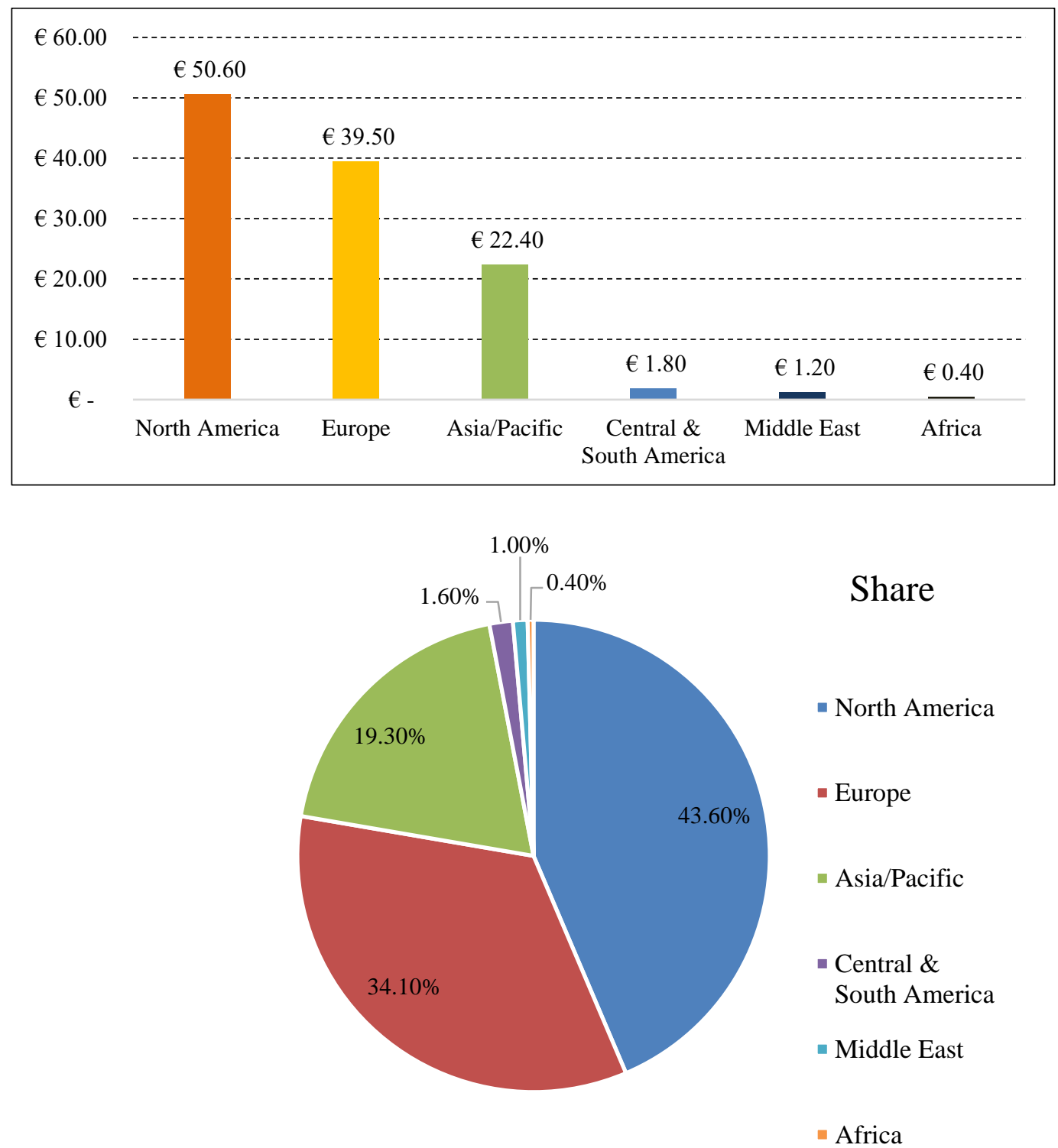

Source: UFI (2019)

Figure 1. Exhibitions direct spending by region 

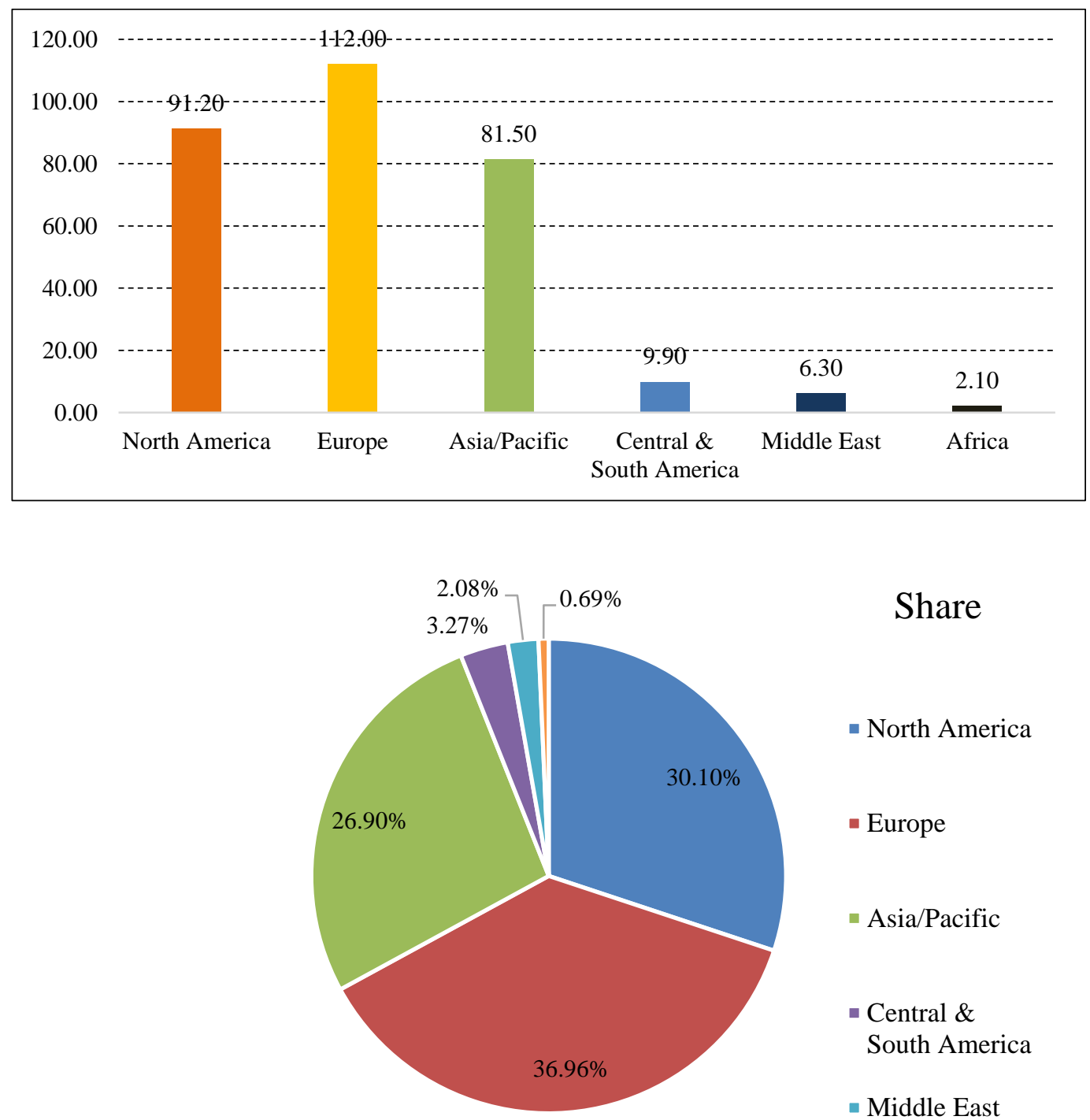

Share

- North America

- Europe

- Asia/Pacific

- Central \&

South America

- Middle East

- Africa

\section{Source: UFI (2019)}

Figure 2. Exhibitions visitors by region in 2018 (million)

In recent years, the deep-seated contradictions in global economic development have been prominent, and trade protectionism and unilateralism have risen. However, under the overall momentum of healthy and stable economic development and long-term stability and improvement, the overall scale of overseas exhibitions has maintained a growth trend along with the effective structural adjustment. Significantly, the number of exhibitors and exhibition area has steadily increased, and the number of exhibitors has gradually increased. Compared with domestic exhibitions, overseas exhibitions can provide companies with excellent business opportunities. It is an efficient marketing method that shows true sincerity in the exhibition and gives more opportunities to contact potential customers. The overseas exhibition has established an exchange platform for Chinese enterprises to carry out economic and trade cooperation with foreign countries and promote the international competitiveness of enterprises and the international market share of commodities. 


\subsection{Participation of China in Overseas Exhibitions}

China's overseas exhibitions in 2013 involved 37 countries, with a 48\% increase of 12 countries compared to 2012 (Table 1 and Table 2). The new countries include Georgia, Singapore, Russia, Egypt, etc. The total exhibition area of the new countries is 24,000 square meters (the number of new countries is 1 exhibition). Compared with 2012, the number of China's exhibitions held in India in 2013 increased by two times (an increase of 200\%), and the exhibition area increased by 6,000 square meters (an increase of $83 \%$ ). The market is developing at a faster rate. The country with the highest increase in overseas exhibitions was Kazakhstan. The number of exhibitions is unchanged. The area increased by 3,886 square meters (an increase of $125 \%$ ).

Table 1. 2012-2018 China's overseas exhibition statistics (the Belt and Road countries)

\begin{tabular}{ccccccc}
\hline & \multicolumn{2}{c}{$\begin{array}{c}\text { Overseas Exhibition } \\
\text { Country }\end{array}$} & \multicolumn{2}{c}{$\begin{array}{c}\text { Number of } \\
\text { Exhibitions }\end{array}$} & \multicolumn{2}{c}{ Exhibition Area } \\
\cline { 2 - 7 } & Number & $\begin{array}{c}\text { Increase } \\
(\%)\end{array}$ & Sum & $\begin{array}{c}\text { Increase } \\
(\%)\end{array}$ & $\begin{array}{c}\text { Total Area }(10,000 \\
\text { square meters })\end{array}$ & $\begin{array}{c}\text { Increase } \\
(\%)\end{array}$ \\
\hline 2012 & 13 & - & 36 & - & 8.9554 & - \\
2013 & 21 & 61.54 & 41 & 13.89 & 9.6600 & 7.87 \\
2014 & 19 & -9.52 & 43 & 4.88 & 15.8744 & 64.33 \\
2015 & 16 & -15.79 & 34 & -20.93 & 15.4964 & -2.38 \\
2016 & 26 & 62.50 & 75 & 120.59 & 49.3838 & 218.68 \\
2017 & 27 & 3.85 & 71 & -5.33 & 46.8657 & -5.10 \\
2018 & 25 & -7.41 & 66 & -7.04 & 32.7400 & -30.14 \\
\hline
\end{tabular}

Source: 2019 Annual Report on China's Exhibition Industry

Table 2. 2012-2018 China's overseas exhibition statistics (non-the Belt and Road countries)

\begin{tabular}{ccccccc}
\hline & \multicolumn{2}{c}{$\begin{array}{c}\text { Overseas Exhibition } \\
\text { Country }\end{array}$} & \multicolumn{2}{c}{$\begin{array}{c}\text { Number of } \\
\text { Exhibitions }\end{array}$} & \multicolumn{2}{c}{ Exhibition Area } \\
\cline { 2 - 7 } & Number & $\begin{array}{c}\text { Increase } \\
(\%)\end{array}$ & Sum & $\begin{array}{c}\text { Increase } \\
(\%)\end{array}$ & $\begin{array}{c}\text { Total Area }(10,000 \\
\text { square meters })\end{array}$ & $\begin{array}{c}\text { Increase } \\
(\%)\end{array}$ \\
\hline 2012 & 11 & - & 25 & - & 5.3076 & - \\
2013 & 16 & 45.45 & 22 & -12.00 & 3.5890 & -32.38 \\
2014 & 18 & 12.50 & 34 & 54.55 & 8.1010 & 125.72 \\
2015 & 12 & -33.33 & 22 & -35.29 & 10.0010 & 23.45 \\
2016 & 24 & 100 & 56 & 154.55 & 29.8395 & 198.37 \\
2017 & 16 & -33.33 & 53 & -5.36 & 35.1960 & 17.95 \\
2018 & 17 & 6.25 & 49 & -7.55 & 25.0100 & -28.94 \\
\hline
\end{tabular}

Source: 2019 Annual Report on China's Exhibition Industry

In 2014, overseas exhibitions involved 37 countries, the same as in 2013. The new countries include Kyrgyzstan, Mongolia, Venezuela, North Korea, Chile, Tajikistan, Ghana, Laos, Cuba, Côte d'Ivoire, Peru, and Pakistan. The total exhibition area of the new countries is 33,000 square meters. Compared with 2013, the number of China's exhibitions held in Hungary and Brazil in 2014 increased by four times (an increase of 200\%), and the exhibition area increased by 11,000 square meters, with an increase of $752 \%$ and $1,464 \%$, respectively. The market is developing very fast. The country with the highest increase in the area of overseas exhibitions was Kazakhstan. The number of exhibitions increased by 3 , 
and the area increased by 13,800 square meters (an increase of 197\%).

In 2015, overseas exhibitions involved 28 countries, with 9 countries less than in 2014. Compared to 2014, the number of China's exhibitions held in Turkey and Indonesia in 2015 increased by two times (an increase of 200\%), and the exhibition area increased by nearly 14,700 and 16,000 square meters, with an increase of $347 \%$ and $800 \%$, respectively. The development speed is breakneck. The country with the highest increase in the area of overseas exhibitions was Kazakhstan. The number of exhibitions increased by 3, and the area increased by 13,800 square meters (an increase of 197\%).

In 2016, overseas exhibitions involved 50 countries, increasing 22 countries compared to 2015 (an increase of 78.6\%). In 2017, overseas self-hosted exhibitions were held in 43 countries, with 7 countries less than 2016. Compared with 2016, the number of China's exhibitions in 9 countries, including the United States, Germany, Iran, and Mexico, increased in 2017. The total exhibition area increased in Pakistan by $1,260 \%$ and in Mexico by $495 \%$. All countries have increased.

In 2018, self-hosted exhibitions outside China involved 42 countries, with one country less than in 2017. Compared to 2017, the number of China's exhibitions in 18 countries has increased, including India, Mexico, Malaysia, and Nigeria. The total exhibition area in Mexico has increased by as much as $300 \%$, and that in Kenya, Pakistan, and Nepal has doubled.

\subsubsection{Participate in Overseas Exhibitions of the Belt and Road Countries}

According to the China Exhibition Economic Development Report 2018 issued by the China Council for the Promotion of International Trade, China's participation in overseas exhibitions increased steadily in 2018. The number of participating exhibitions in the Belt and Road countries increased by $14.3 \%$. China's 92 exhibitors went to 66 countries to participate in 1,672 exhibitions, an increase of 4.89\% year-on-year; 59,000 exhibitors, the same as the previous year. In terms of the exhibition format, in 2018, China's overseas exhibitions were mainly exhibited abroad, with a total of 1,519 items, a year-on-year increase of 5.4\%. 153 exhibitions were held abroad, a year-on-year increase of $9.3 \%$. The main exhibition countries were Brazil, Indonesia, Russia, and other 45 countries, with general exhibitions, machinery, textiles and clothing and leather products, and architectural decorations as the main exhibits.

As the construction of the Belt and Road has entered the accelerated stage, China's participation in exhibitions in countries along the Belt and Road has steadily increased. In 2018, 76 exhibitors from China went to 33 countries along the Belt and Road to participate in 718 exhibitions, with 26,000 exhibiting companies. The participating exhibition industries were mainly comprehensive and mechanical exhibitions. The top 10 countries in terms of the number of projects are Russia, India, UAE, Turkey, Thailand, Indonesia, Vietnam, Iran, Singapore, and Malaysia.

\subsubsection{Global Trends in Overseas Exhibitions}

In 2019, 91 exhibitors from China participated in 1,766 exhibitions in 73 countries, a year-on-year increase of 5.6\%; exhibition area was 921,300 square meters, a year-on-year increase of $11.0 \%$; 61,000 exhibitors, a year-on-year increase of 3.39\%. In 2019, China's overseas exhibitions are still the mainstream. The number of overseas exhibitions shows a downward trend. Among them, 1,634 exhibitions abroad account for 92.5\% of the total number of overseas exhibitions, a year-on-year increase of 7.6\%. Participating countries mainly include the United States, Germany, Russia, India, the United Arab Emirates, Japan, Brazil, Thailand, Mexico, Vietnam, etc. Among them, the largest number of exhibitors in 
the United States reached 266, accounting for $14.4 \%$ of the total number of overseas exhibits, followed by Germany, 223 exhibits, accounting for $13.6 \%$.

In 2019, China held 132 exhibitions abroad, accounting for $7.5 \%$ of the total number of participating exhibitions abroad, a year-on-year decrease of $13.7 \%$. The main exhibition countries are Indonesia, Thailand, South Africa, Poland, India, France, Russia, Nigeria, the Philippines, Malaysia, etc. Among them, there are 8 exhibitions in Indonesia, accounting for $6.0 \%$; followed by Thailand, 7 exhibitions, accounting for 5.3\%; South Africa, Poland, India, and France are tied for third place, all of which are 6, accounting for $18.2 \%$.

Compared with 2018, the total area of China's overseas exhibitions in 2019 accounted for a relatively high proportion and increased; the area of overseas exhibitions accounted for a relatively low proportion, which has fallen relative to 2018. Among them, the area of overseas exhibitions was about 667,000 square meters, accounting for $72.4 \%$ of the total area of overseas exhibitions, an increase of $17.7 \%$; the area of overseas exhibitions was 254,400 square meters, accounting for $27.6 \%$ of the total area of overseas exhibitions, a year-on-year decrease of $3.4 \%$. In 2019, the number of Chinese exhibitors abroad accounted for a high proportion and increased compared with 2018, while the number of exhibitors abroad declined compared with 2018. About 47,000 exhibitors went abroad, accounting for $77.9 \%$ of the total number of exhibitors, a year-on-year increase of $12.4 \%$, about 13,000 exhibitors abroad, accounting for $22.1 \%$ of the total exhibitors, a year-on-year decrease of $19.4 \%$.

From the regional distribution of China's overseas exhibitions, traditional European and American markets are still the mainstay, emerging markets actively in Asia, and the indepth development of emerging markets such as Latin America and Africa has made significant progress. The regions where China will hold exhibitions abroad in 2019 are mainly concentrated in Asia, Western Europe, and North America. The three regions rank in the top three to participate in exhibition projects, areas, and companies. As shown in Figure 3, Asia is still the most important exhibition market where the number of participating exhibition projects, exhibition area, and the number of participating companies have all increased. The number of participating exhibition projects and participating exhibition areas in Western Europe and North America have only achieved a small growth along with a decline in the number of participating exhibition companies. The number of participating exhibition projects and the participating exhibition area in Eastern Europe and Russia continues to grow along with a decline in the number of participating companies. The enthusiasm for participating in exhibitions in Latin America and the Caribbean rebounded, and the number of participating exhibition projects, exhibition area, and the number of participating companies have all increased compared with last year. The number of participating exhibition projects, exhibition area and the number of participating companies in Africa and Oceania are still small, but both maintain rapid growth. 


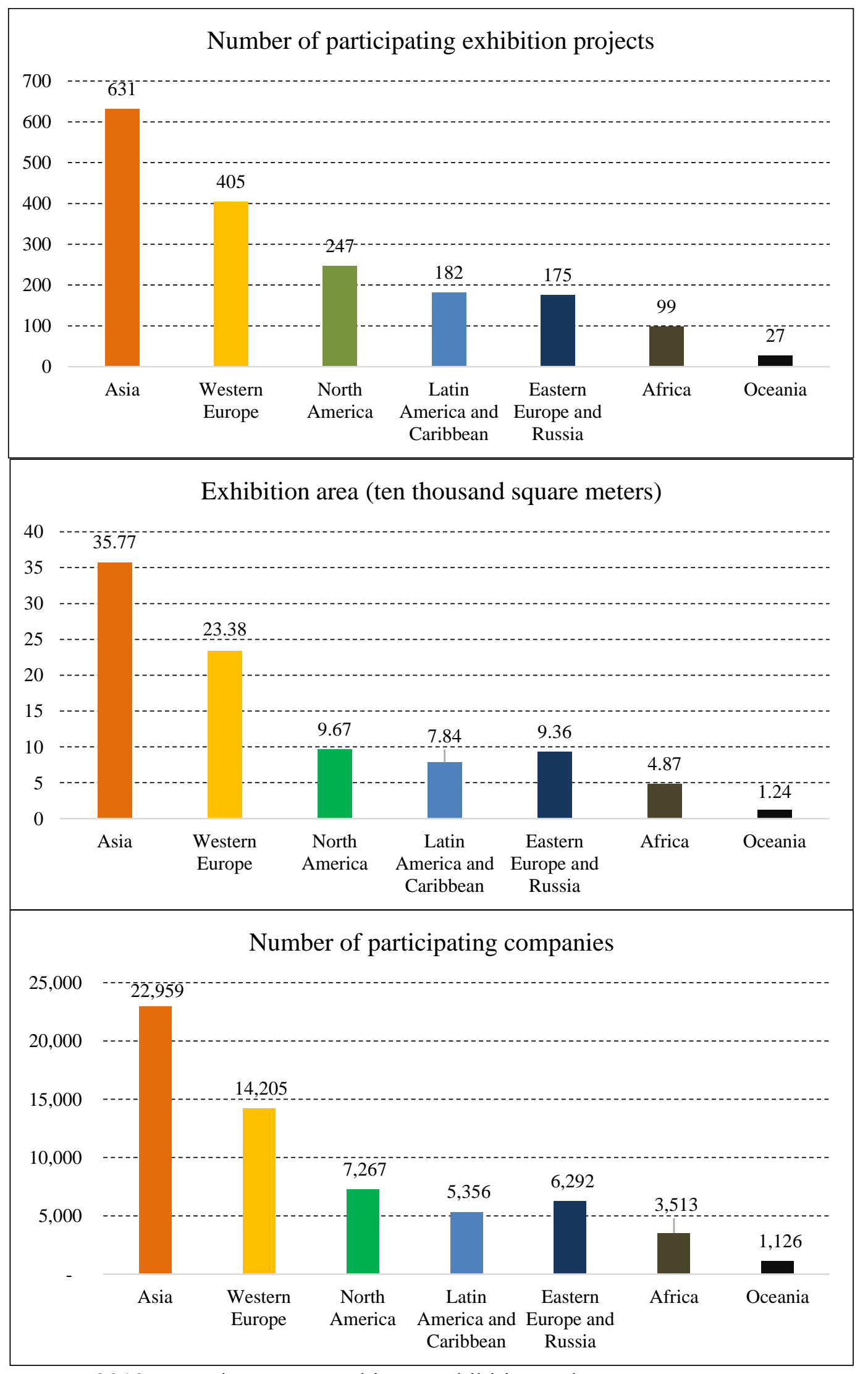

Source: 2019 Annual Report on China's Exhibition Industry

Figure 3. The number of China participating in exhibition projects, exhibition area, and number of participating companies in each continent in 2019 


\section{Research on the Correlation of China's Exhibition to the Preference Similarity Theory}

\subsection{Methodology: Preference Similarity Theory}

Preference Similarity Theory (PST) is an economics conjecture about international trade patterns: the more similar the demand structures of countries, the more they will trade with one another. Further, international trade will still occur between two countries with identical preferences and factor endowments relying on specialization to create a comparative advantage in producing differentiated goods between the two nations.

PST is also called Overlapping Demand Theory. The hypothesis was proposed as a possible resolution to the Leontief paradox (Linder, 1961), which questioned the empirical validity of the Heckscher-Ohlin theory $(\mathrm{H}-\mathrm{O})$. $\mathrm{H}-\mathrm{O}$ predicts that the relative factorendowments of different nations will determine patterns of international trade. Those with relatively high capital levels in relation to labor would be expected to produce capitalintensive goods, while those with an abundance of labor relative to (immobile) capital would be expected to produce labor-intensive goods. $\mathrm{H}-\mathrm{O}$ and other theories of factor-endowment based trade had dominated the field of international economics until Leontief performed a study empirically rejecting H-O. In fact, Leontief found that the United States (then the most capital abundant nation) exported primarily labor-intensive goods. Linder proposed an alternative theory of trade that was consistent with Leontief's findings. The Linder hypothesis presents a demand-based theory of trade compared to the usual supply-based theories involving factor endowments. These nations would then trade with each other in similar but differentiated goods.

Examinations of the Linder hypothesis have observed a "Linder effect" consistent with the hypothesis. Econometric tests of the hypothesis usually proxy the demand structure in a country from its GDP per capita. It is convenient to assume that the closer are the income levels per consumer, the closer are the consumer preferences. The econometric test of the hypothesis has been difficult because countries with similar GDP per capita are generally located close to each other geographically, and distance is a critical factor in explaining trade intensity between two countries. Generally, a Linder effect is more significant for trade in manufactures than for non-manufacturers (Francois \& Kaplan, 1996). The establishment of the PST is based on two hypothetical conditions:

\subsubsection{Assumptions on Different Demand Structures (or Consumer Behavior Assumptions)}

Demand is determined by the income level of consumers within a country. Assume that consumers with higher incomes will prefer luxury goods, and consumers with lower incomes will prefer necessities. In general, a country has the greatest demand for the average grade of goods will become the representative demand.

\subsubsection{Assumptions on the Overlap of Demand between the Two Countries}

Suppose that the manufacturer decides its production direction and content according to the consumer's income level and demand structure, and the necessary condition for production is the existence of effective demand for its products. If the average income levels of the two countries are similar, the two countries' demand structure is also similar. Conversely, if the two countries' income levels differ greatly, there must be a significant difference in their demand structure.

Also, there is still a lack of specifying the direction of trade flows according to the difference in consumption propensity caused by the heterogeneity of products and the 
differentiation of domestic income levels (high-income people consume imported products, and low-income people consume domestic products). However, PST hypothesizes that nations with similar demands would develop similar industries, which significantly interpreted the rapid development between developed countries since World War II and became the foundation of intra-industry trade.

\subsection{Data Analysis}

In recent years, many scholars have conducted empirical researches on China's foreign trade data to conform to the PST. Jiang \& Wu (2009) used mathematical models to conduct an empirical analysis of China's country-specific trade structure in 2007 . The empirical results show consistency. Zhao \& Xie (2017) used lognormal distribution to fit the income distribution curve between China and 63 trading partner countries. HS92 six-digit code was employed to subdivide the trade commodity data to test China's imports. The results show a significant promotion effect on China's import demand, which can better explain the import trade between China and developed countries.

However, the income level of various countries may not truly reflect demand preferences. Many factors determine demand preferences. Li \& Cao (2005) believed that even if trading partner countries had the same income level and demand preferences, under the conditions of an open market economy, differences in the relative prices of goods and services as well as the regional trade agreements will cause the trade structure to deviate from the similarity theory of demand preference. Huo (2008) also combined empirical analysis and experiencing analysis to demonstrate that the deviation of China's cultural trade from the PST was determined by cultural trade characteristics, which is different from general goods trade. Sun (2014) used trade data to conduct an empirical study on the impact of PST on Zhejiang cultural industry trade. The results confirmed that the scale and direction of Zhejiang cultural industry trade meet the theory.

With the continuous opening policy, more and more companies have participated in overseas exhibitions product demonstration and brand image, which is important to enhance the international competitiveness of Chinese companies. Zhang (2018) discussed why individual exhibitors are not very aware of intellectual property rights, and some developed countries used intellectual property law enforcement to strengthen trade protection. Companies with strong intellectual property awareness in the United States, Germany, and other countries have focused on the protection of their rights on Chinese companies, which often suffered from intellectual property issues at overseas exhibitions (Liu, 2014; Huang, 2014; Pei, 2017; Yu, 2017).

Although participating in overseas exhibitions is an effective way for companies engaging in international competition, there are still problems such as weak participation awareness, unclear participation goals, and unsatisfactory results. The subsidy policy for overseas exhibitions positively affects encouraging companies to explore the international market with certain results (Wang, 2016). In the formulation and implementation of the policy, however, there are also problems related to long application period, cumbersome procedures, difficult audits, and delayed release. The effects of subsidy implementation and business participation are drained.

Unlike overseas exhibition participating, the number of exhibition venues and exhibition organizers outside China has decreased in recent years, but the exhibition area has increased (Zhao, 2016). In the process of overseas exhibitions, China has held a large exhibition area in India, Thailand, Brazil, and other countries, and the exhibition area was increasing at a relatively fast rate each year. From a certain perspective, it is benign for constant numbers of the exhibition with increasing areas of the exhibition. 
Currently, the regions where China holds exhibitions are still dominated by traditional markets in Europe and America. Emerging markets in Asia are becoming more active, and the in-depth development of emerging markets such as Latin America and Africa has made significant progress. Moreover, China has the same per capita GDP levels and demand preferences as those of the Belt and Road trading partners and the same total GDP levels and open market economic conditions as non-the Belt and Road trading partners. China's expansion of overseas exhibitions can be tested through empirical analysis of whether the trade structure deviates from the PST.

Based on the number of exhibitions and exhibition area of China's overseas self-hosted exhibitions in various venues from 2012 to 2018, this research empirically tested the PST according to the Belt and Road countries and non-the Belt and Road countries. Data on total GDP and per capita GDP are used to detect whether a closer income level between the two countries resulted in similar demand preferences with a larger overseas exhibition index (the sum of the number of exhibitions and the exhibition area). Therefore, the overseas exhibition index and the income gap index should present a negative correlation.

Tables 3 and 4 show respectively the number and area of exhibitions held overseas in China from 2012 to 2018 in the Belt and Road countries and non-the Belt and Road countries and the total GDP and per capita GDP of these countries over the years. The number of exhibitions held in countries along the Belt and Road reached its highest peak in 2016 (79 times). Even though it declined in 2018, it still maintained about 70 times a year. The average exhibition area also fluctuated with the number of exhibitions held, reaching the highest peak in 2016 (18,833 square meters).

The number of China's exhibitions held in non-the Belt and Road countries has been slightly lower than that in the Belt and Road countries over the years. It also reached a peak in 2016 (56 times). Although it declined in 2018, it has maintained about 50 exhibitions per year. The average exhibition area also changed approximately with the number of accompanying exhibitions fluctuates, reaching the highest peak in 2017 (18,628 square meters).

Tables 3 and 4 also show that the total GDP (approximately US\$200 billion) and per capita GDP (approximately US\$13,000) of the Belt and Road countries over the years are lower than those of non-the Belt and Road countries, indicating that the Belt and Road countries are, in general, mostly developing countries with lower per capita GDP.

Table 3. China's overseas exhibitions and income from the Belt and Road countries

\begin{tabular}{ccccc}
\hline & \multicolumn{3}{c}{ Exhibition abroad } & \multicolumn{2}{c}{ GDP } \\
\cline { 2 - 5 } & number & $\begin{array}{c}\text { Average area } \\
\text { (square meters) }\end{array}$ & $\begin{array}{c}\text { GDP (100 million } \\
\text { US dollars) }\end{array}$ & GDP per capita \\
\hline 2012 & 41 & 6,563 & 2,227 & 14,803 \\
2013 & 46 & 4,858 & 2,314 & 14,889 \\
2014 & 48 & 8,674 & 2,318 & 14,546 \\
2015 & 37 & 10,813 & 2,056 & 11,891 \\
2016 & 79 & 18,833 & 2,081 & 11,216 \\
2017 & 74 & 18,095 & 2,192 & 12,247 \\
2018 & 71 & 13,859 & 2,344 & 12,959 \\
\hline
\end{tabular}

Source: China Conference and Exhibition Economic Research Association, IMF "World Economic Outlook" 
Table 4. China's overseas exhibitions and income from non-the Belt and Road countries

\begin{tabular}{ccccc}
\hline & \multicolumn{2}{c}{ Exhibition abroad } & \multicolumn{2}{c}{ GDP } \\
\cline { 2 - 5 } & number & $\begin{array}{c}\text { Average area } \\
\text { (square meters) }\end{array}$ & $\begin{array}{c}\text { GDP (100 million } \\
\text { US dollars) }\end{array}$ & GDP per capita \\
\hline 2012 & 25 & 4,825 & 13,646 & 19,532 \\
2013 & 23 & 2,138 & 13,678 & 19,461 \\
2014 & 36 & 4,331 & 13,954 & 19,395 \\
2015 & 23 & 7,770 & 13,160 & 17,397 \\
2016 & 56 & 12,433 & 13,393 & 17,415 \\
2017 & 54 & 18,628 & 13,996 & 18,280 \\
2018 & 50 & 14,006 & 14,748 & 19,326 \\
\hline
\end{tabular}

Source: China Conference and Exhibition Economic Research Association, IMF "World Economic Outlook"

Table 5 shows the level of total GDP and per capita GDP in China over the years. The GDP has grown rapidly year by year and is almost 10 times the total GDP of the Belt and Road countries in 2018. However, China's per capita GDP is lower than that of the Belt and Road countries (about 75\%).

Table 5. China's income over the years

\begin{tabular}{lcc}
\hline & GDP (100 million US dollars) & GDP per capita \\
\hline 2012 & 85,704 & 6,329 \\
2013 & 96,350 & 7,081 \\
2014 & 105,345 & 7,702 \\
2015 & 112,262 & 8,167 \\
2016 & 112,321 & 8,123 \\
2017 & 122,428 & 8,583 \\
2018 & 131,187 & 9,377 \\
\hline
\end{tabular}

Source: Ministry of Commerce

An empirical test of the PST using overseas exhibitions presents that the closer the income of the two countries is (the smaller the gap between total GDP or per capita GDP), the higher the overlap of demand preferences and the higher the overlap of trade demand expressed by exhibitions. In other words, the numbers of China's overseas exhibitions and the exhibition area are negatively correlated with the gap between the two countries in total GDP or per capita GDP.

Table 6 reveals the test results of the correlation coefficient of the PST in terms of overseas exhibitions. The PST of overseas exhibitions shown by the total GDP gap is established in the Belt and Road countries (except in 2012 and 2014) and non-the Belt and Road countries, and the correlation coefficients are both negative and significant. The PST of overseas exhibitions shown by the gap in per capita GDP is established in the Belt and Road countries, and the correlation coefficients are all negative and significant. Nevertheless, it is only established in 2018 in non-the Belt and Road countries.

In terms of changing trends over the years, the PST for overseas exhibitions measured by the total GDP gap shows that China has always maintained a strong mutual trade demand with non-the Belt and Road countries, while mutual trade demand with the Belt and Road countries has become increasingly strong, nearly replacing non-the Belt and Road countries in 2018 (as shown in Figure 2). 
Table 6. Theoretical test of Preference Similarity Theory (Correlation Coefficient)

\begin{tabular}{ccccc}
\hline & \multicolumn{2}{c}{ GDP gap } & \multicolumn{2}{c}{ GDP per capita gap } \\
\cline { 2 - 5 } & $\begin{array}{c}\text { Belt and Road } \\
\text { countries }\end{array}$ & $\begin{array}{c}\text { non-the Belt and } \\
\text { Road countries }\end{array}$ & $\begin{array}{c}\text { Belt and Road } \\
\text { countries }\end{array}$ & $\begin{array}{c}\text { non-the Belt and } \\
\text { Road countries }\end{array}$ \\
\hline 2012 & 0.2166 & -0.5779 & -0.1774 & 0.7406 \\
2013 & -0.1638 & -0.6321 & -0.1218 & 0.5502 \\
2014 & 0.0005 & -0.6277 & -0.0109 & 0.4406 \\
2015 & -0.6768 & -0.8579 & -0.3122 & 0.4567 \\
2016 & -0.7165 & -0.5338 & -0.1882 & 0.2581 \\
2017 & -0.5710 & -0.6395 & -0.4196 & 0.3695 \\
2018 & -0.8444 & -0.1169 & -0.1951 & -0.2854 \\
\hline
\end{tabular}

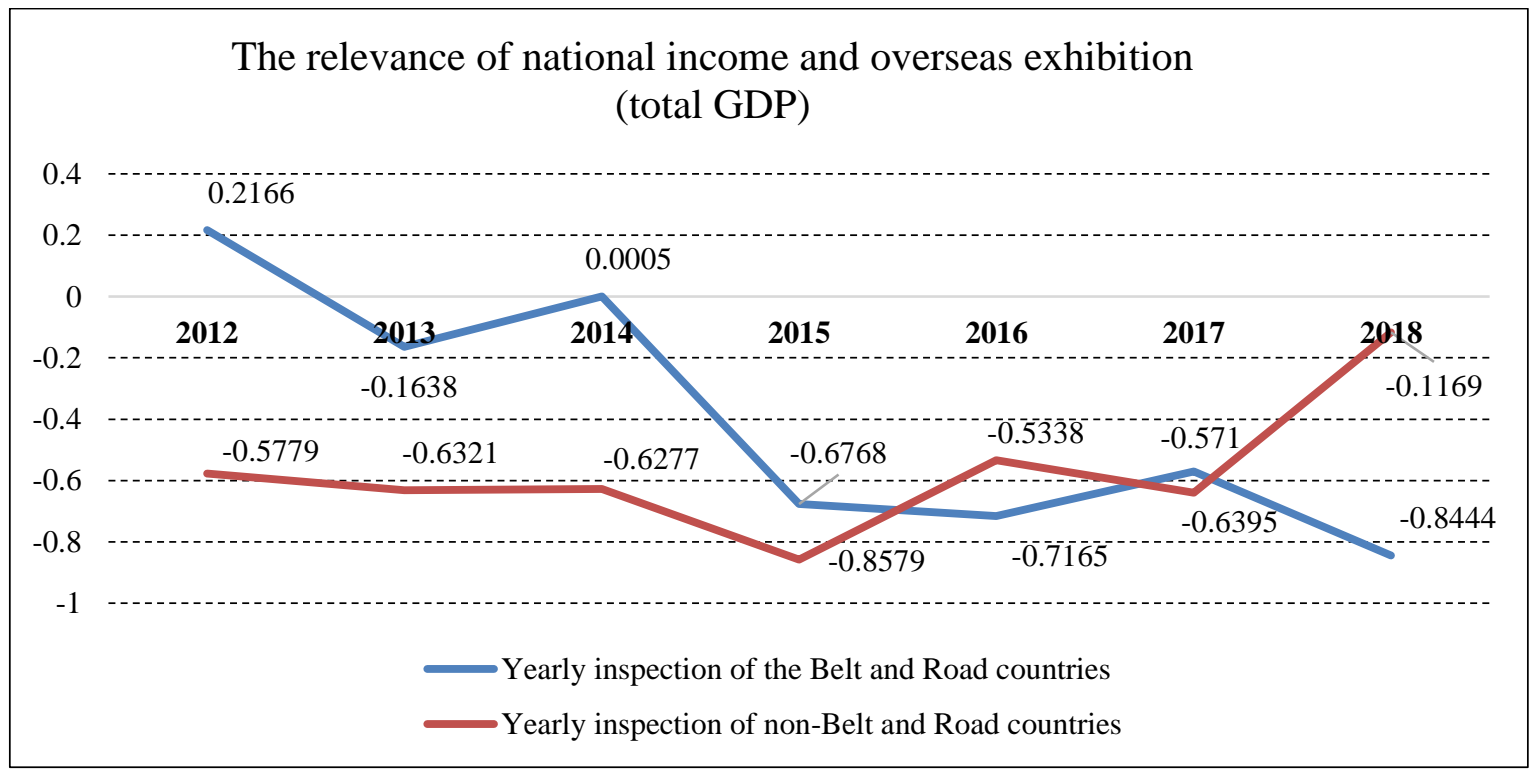

Source: Analysis and collation of this research

Figure 2. The correlation coefficients between national income and overseas exhibition measured by total GDP

The PST for overseas exhibitions measured by the gap in per capita GDP shows that China has always maintained a strong mutual trade demand with countries along the Belt and Road, while the mutual demand for trade with non-the Belt and Road countries has gradually increased. Finally, PST is demonstrated in 2018 (as shown in Figure 3).

2019 is the mark of the $6^{\text {th }}$ anniversary of the Belt and Road with fruitful results. China has actively promoted exhibition organizers to participate in exhibitions in countries related to the Belt and Road. It has continuously built a platform for enterprise docking and a growing circle of friends for the Belt and Road with more trade partners, higher quality of cooperation, and better development prospects. Starting from 2019, China no longer pursued the quantity for participating in exhibitions in countries along the Belt and Road but paid more attention to concentrated participation or holding large exhibitions for higher quality exhibitions. However, participating in exhibitions in countries along the Belt and Road showed a centralized trend. The top 10 countries in the number of projects are Russia, India, UAE, Thailand, Vietnam, Turkey, Indonesia, Malaysia, Poland, and the Philippines. They have participated in 599 exhibitions in the above 10 countries, accounting for $85.9 \%$ of the total number of exhibition projects. The participating exhibition area is 348,000 
square meters, accounting for $84.9 \%$ of the total exhibition area of the countries along the Belt and Road. There were 22,000 participating companies, accounting for $85.9 \%$ of the total (2019 China Exhibition Economic Development Report).

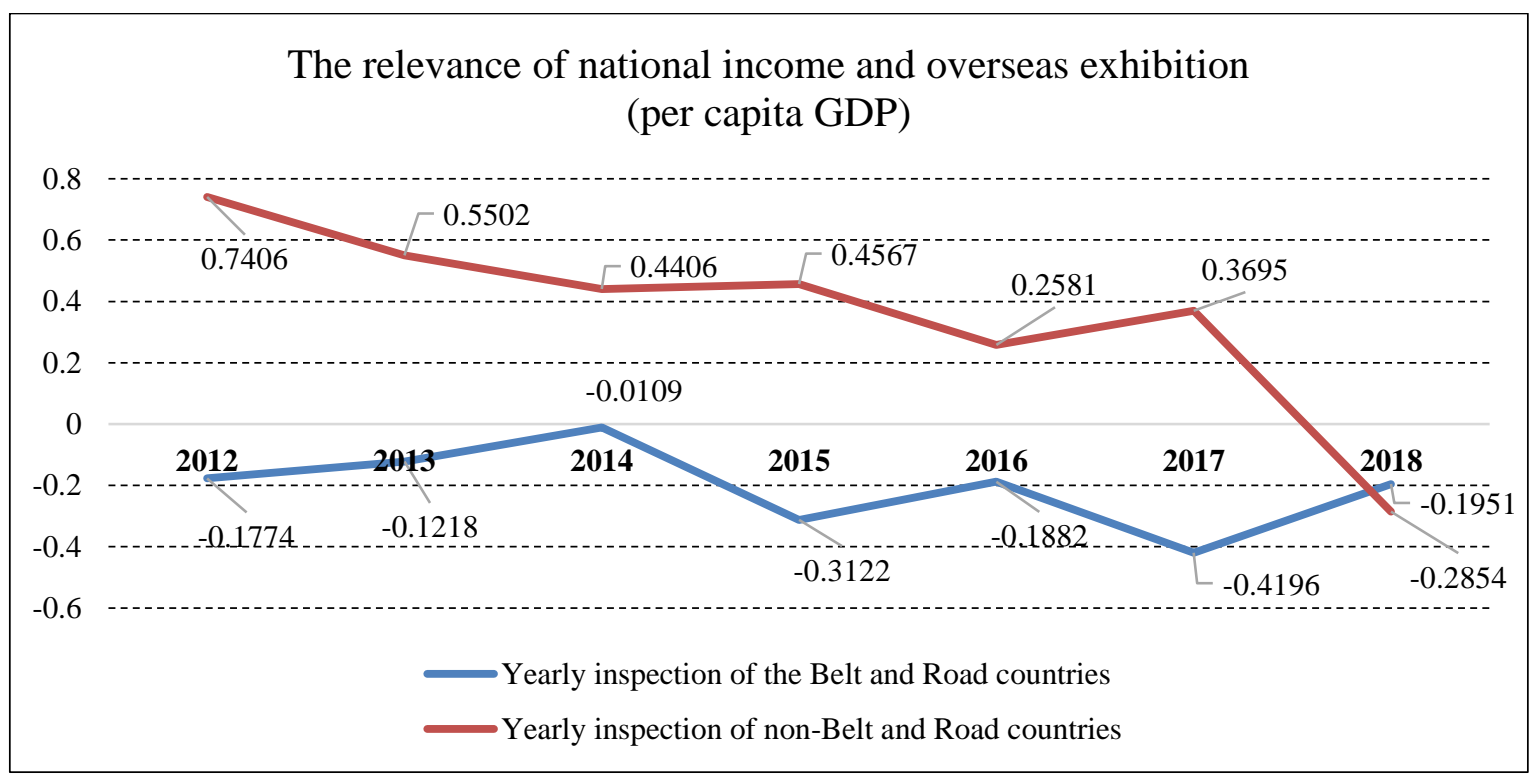

Source: Analysis and collation of this research

Figure 3. The correlation coefficients between national income and overseas exhibition measured by total per capita GDP

\section{Suggestions on the Future Trends in Overseas Exhibitions}

This paper has demonstrated the applicability of the PST in China's development of exhibitions. With a view of the differences between China's participation in the Belt and Road and non-the Belt and Road countries' overseas exhibitions and the development trends of foreign exhibitions in recent years, we propose some countermeasures for China's exhibition industry on the trends of future global overseas exhibitions layout.

\subsection{New Trends in the Development of International Exhibitions}

The current development level and pattern of international exhibitions are basically consistent with the overall situation of world economic development. Most developed countries have a good foundation for exhibition activities, rich experience in organizing exhibitions, numerous brand exhibitions, and strong competitiveness in the exhibition industry, while the exhibition industry in developing countries is also making rapid progress. With the further improvement of the scientific and technological level of various countries as well as the economic system, international exhibitions have shown the following development trends:

\subsubsection{More Specialization of the Development of the Exhibition Industry}

Professional exhibitions have become the mainstream of the exhibition industry's development and represent the development trend of the exhibition economy. Compared with general exhibitions, professional exhibitions have the characteristics of strong pertinence, high quality of exhibitors, and good exhibiting effects. Commercial marketability is strong in attracting professional suppliers, distributors, and end consumers to the maximum which increase the interaction between supply and demand. In recent years, the convention and exhibition powers in Germany, Italy, France, and the United States have 
continuously reduced the number of comprehensive exhibitions. Many comprehensive exhibitions have been subdivided into several professional exhibitions, demonstrating an important trend of exhibition industry development.

\subsubsection{Scale-up of the Exhibition}

With the increasingly fierce competition in exhibitions, the organizers are no longer limited to attracting exhibitors from their own countries or regions but focus more on the international market. They expand domestic and even regional influence and strive to increase participation in the international market. Governments of various countries have increased their support for the exhibition industry, especially the construction of the infrastructure of large-scale exhibition venues to offer various policy supports. Meanwhile, the development of urbanization has a great demand for city image and investment promotion, promoting the development of the regional exhibition economy. Large-scale means that a highly concentrated group of exhibitors can deeply reflect the professionalism and representativeness of the exhibition industry. Large-scale exhibitions generate speeding development and stronger product competitiveness.

\subsubsection{The Alliance between Giants and Increasing Grouping of International Operation}

Mergers and Acquisitions (M\&A) and alliances have swept across all fields of the global economy and have become a major focus of the international market. It is also the case of a highly internationalized exhibition. The M\&A and cooperation of exhibition enterprises through the operation of capital is a typical international operation. Through $\mathrm{M}$ $\&$ A and cooperation, domestic and international resources can be used to develop domestic and international markets to obtain an optimal allocation of resources. As a high-profit industry, the exhibition industry is an industry with large investments and quick returns. Its profit rate is as high as $25 \%$. It is manifested in the microscopic field, which enhances the requirements of the total assets, human resources, and technical strength of exhibition enterprises. Therefore, the competition in the industry is fierce. To reduce costs and risks to maintain high-profit margins, giants in the international exhibition industry establish strategic alliances through mergers and cooperation, conduct international operations, continuously optimize their capital structure, and increase market share.

\subsubsection{Application of Modern New Technology in the Exhibition Industry}

With the continuous development of information technology, exhibition companies have begun to introduce modern information management systems. Hannover-based Deutsche Messe, a globally leading producer of capital goods trade fairs in Germany and worldwide, has established a network data interactive platform based on customer relationship management. Using the global online business information system, they can share exhibition information through the interactive platform to achieve "point-to-point, many-to-many" dialogue. They helped exhibitors integrate customer resources, sales management, market services, and marketing decisions to improve efficiency.

\subsubsection{Rise of Fresh Blood and Diversification of Host Countries}

In recent years, the exhibition industries in developing countries, especially China, Singapore, South Korea, Japan, and the Asia-Pacific regions, have risen rapidly. Its position in the international exhibition industry has been significantly improved. For example, Hong Kong, known as the "Exhibition Capital of Asia", attached great importance to developing the exhibition market and related products where thousands of international conferences and 
exhibitions are held every year. China has achieved leapfrog development, ranked second in the world in terms of comprehensive ranking, and consolidated its status of a major convention and exhibition country by reaching the top of the exhibition number. As an important platform for international trade exchanges in today's economic globalization, exhibitions play a vital role in the economic development. They rely on transplanting multinational exhibition brands, vigorously developing domestic exhibitions, striving to share benefits in the international exhibition market, leading to the country where the exhibition is held to break the traditional western monopoly trend and present diversification.

\subsubsection{Seize International Exhibition Market through Capital Export and Brand Transplantation}

In the development of world exhibitions towards specialization and collectivization, exhibitions in European and American have been quite developed and leave less room for domestic development. To seek global development, international exhibition giants have set their targets overseas, seek low-cost expansion through capital operations, and enter the markets of developing countries where trade fairs are relatively backward. In addition, they make full use of their extensive business network to transplant some famous exhibition brands to other countries. The transnational operation meets the needs of the international market and seizes the share of the world exhibition market.

\subsubsection{Professional and Market-oriented Operation}

Leading countries in the world exhibitions all adopt a market-oriented operation model to carry out communication services, face the market, use the market, serve the market, develop the market, and implement company operations through market mechanisms. Large-scale exhibitions significantly stimulate the accommodation, catering, transportation, logistics, advertising, and tourism shopping industries in the host city. At the same time, a large number of professional organizations and exhibition activists with exhibition organization and service as their profession have emerged. The convention and exhibition industry has created a huge number of full-time jobs, government tax revenues, corporate turnover, and as a result, huge economic benefits.

\subsection{Enlightenment of the Experience of Foreign to China}

As new blood of modern international trade, exhibitions have been taken advantage of the huge promotion and influence by many developed countries to the development of their country's trade economy. We propose some important enlightenments for the future development of China's foreign exhibitions.

\subsubsection{It Is Necessary to Strengthen Macro-management and Change the Situation of Domestic Exhibitions Held without a Leader}

Exhibitions in developed countries have set up a unique, independent, and authoritative management organization. For example, the International Association for Exhibition Management (IAEM), Association of the German Trade Fair Industry (AUMA), Centre français des manifestations à l'étranger (CFME-ACTIM), Confederation of British Convention and Exhibition Industry (EFI), etc.

However, China is in short of authority for managing exhibitions. The approval units for exhibitions include the Economic and Trade Commission, the Council for the Promotion of International Trade, and the Ministry of Commerce Approval. There is no effective coordination and quantity control, which results in serious market disorder. To regulate the market, China should set up a special management agency to merge the powers of various 
departments and improve the work efficiency of overseas exhibitions. The government should support the industry to speed up M\&A and establish an internationally competitive Expo Group, thereby strengthen the information exchange and project alliances in various cities, effectively integrate domestic resources, and design the characteristics and advantages of commercial platforms in various industries.

\subsubsection{Transformation of Government Functions and Support of Overseas Exhibitions}

As a form of the service industry, the government's role should be a service provider than a direct manager. The governments of developed countries have clarified the responsibilities, and the involvement of government departments in exhibitions is mainly reflected in the funding and investment. The governments should less intervene in the internal affairs of overseas exhibitions and actively transfer power to relevant industry associations for management. The government's main responsibility is to find ways to plan for the development of overseas exhibitions and provide necessary easing policies and financial support. For example, Messe Frankfurt is one of the largest exhibition companies in Germany and a public company. The city government (City of Frankfurt) holds $60 \%$ of the shares but does not charge any fees. All profits are used for reinvestment. This approach can help exhibition companies quickly complete the original accumulation and achieve the goal of maintaining and increasing the value of state-owned assets.

\subsubsection{Actively Cultivate Overseas Exhibition Brand}

Taking advantage of the impact of economic globalization, many multinational exhibition giants rely on the industries in their cities and/or regions to combine the main exhibition areas with their own industries. The development characteristics are closely related, and the brand effect has been formed. Many well-known international exhibitions rely on local advantageous industries, such as the Paris Fashion Culture Exhibition, Hannover Messe, Dusseldorf International Printing and Packaging Exhibition, etc. These professional exhibitions have allowed the host city to accumulate a strong influence in international exhibitions and build a local city's exhibition brand. With the development of One Belt and Road and the pressure of foreign capital entering the domestic exhibition market, the Chinese government and relevant industry associations should actively guide various localities to cultivate overseas exhibition brands according to their own industrial characteristics and resource conditions and to jointly create a win-win situation with each feature in order to gain a foothold in the exhibition market. Simultaneously, it is necessary to absorb the advanced experience and management methods of well-known foreign manufacturers to improve the visibility of its own corporate exhibition projects.

\subsubsection{Attach Great Importance to the Service Level of the Exhibition Industry}

The exhibition is a special industry. The organizer's service level affects the sustainable development of the exhibition enterprise, and having a good service concept will win the exhibitors and visitors. Although exhibition companies have been involved in other industries, the nature as a service industry has not changed. They must still adhere to the customer-centric concept.

Based on big data, modern exhibitions deeply integrate exhibition resources through cloud computing to implement meticulous customer personalization demand and to increase user participation. The services must be not only comprehensive but also convenient. They provide guides for booking, inquiry, and online service navigation to shorten the traditional service time. The services of the exhibition must be in line with international standards. Internationally accepted standards and procedures should be used when participating in 
large-scale overseas exhibitions. Simultaneously, the construction of logistics supporting service facilities related to exhibitions should be actively improved to provide exhibitors with a "one-stop-shop." The thoughtful and meticulous services, such as transportation, catering, accommodation, legal consultation, advertising, etc., have left overseas exhibitors and visitors a good reputation.

\subsubsection{Vigorously Develop Higher Education and Actively Attract Outstanding Talents}

One of the main reasons for developing exhibitions in developed countries is to have a whole system of training for exhibition talents from "universities to enterprises." To solve the shortage of professional overseas exhibition talents as soon as possible, the government should increase capital investment in colleges and universities and train relevant convention and exhibition colleges to actively adapt to the needs of regional economies and social development for the convention. The government should also integrate disciplines and social resources to optimize professional training goals combined with their own characteristics (Xiao \& Ding, 2018). As companies participating in overseas exhibitions, they should also train overseas exhibition talents through regular holdings. Special training courses and cooperation with internationally renowned exhibition companies could strengthen their school-enterprise cooperation with relevant colleges and promote the integration of production, education, and research.

\subsubsection{Use IT to Strengthen Exhibition Innovation, Create Informatization of Exhibition Methods, Cyberize Marketing and Promotion, Construct Intelligent Venue, and Virtualize Physical Exhibitions}

With the rise of the Internet and the booming of We-Media, the use of the official website, Weibo, WeChat has increased significantly, and the official account and professional information platform have been widely used. A new form of "online exhibition" has also appeared in exhibitions, and IT has created a huge imagination for the new model of "conference + internet." The development of VR, AR, 3D printing technology, etc. has allowed consumers to experience the exhibits further. As an external driving force to promote a new round of transformation of the exhibition industry, "Internet +" will have a transformative impact and force on the traditional exhibition industry, stimulate the adjustment of the exhibition model, improve service efficiency and service quality, rebuild the industrial chain, and reconstruct the industrial structure.

\section{References}

1. UFI (2019). UFI Global Exhibition Barometer. $23^{\text {rd }}$ Edition.

2. Linder, S. B. (1961). An essay on trade and transformation. Stockholm: Almqvist \& Wicksell.

3. Francois, J. F., \& Kaplan, S. (1996). Aggregate demand shifts, income distribution, and the Linder hypothesis. The Review of Economics and Statistics, 78(2), 244-250.

4. Huang, S. B. (2014). Patent risks and countermeasures of Chinese SMEs participating in overseas exhibitions. Journal of Jiangnan University (Humanities and Social Sciences Edition), 13(6), 33-39.

5. Huo, B. G. (2008). An empirical test of the deviation of Chinese cultural trade from the demand similarity theory, Research on Financial Issues, 7, 15-18.

6. Jiang, G. Z., \& Wu, H. W. (2009). An empirical test of the consistency between China's foreign trade structure and demand similarity theory-An analysis based on 2007 data. Journal of Guangdong University of Foreign Studies, 20(2), 36-39.

7. Li, G. J., \& Cao, Y. Q. (2005). An empirical analysis of the similarity theory of demand 
preferences in China's trade. Journal of Yunnan University of Finance and Trade, 3, 27-32.

8. Liu, C. Y. (2014). Beware of intellectual property disputes when participating overseas. Chinese and Foreign Toy Manufacturing, 5, 80-81.

9. Pei, H. (2017). How to play the intellectual property card for overseas exhibitors? China Intellectual Property News, 2017-06-21 (011).

10. Sun, J. J. (2014). Research on the development of Zhejiang cultural industry trade based on the similarity theory of demand preference. Modern Economic Information, 5, 386-387.

11. Wang, Y. H. (2016). Investigation and policy research on the status quo of Jiangxi enterprises' overseas exhibitions (Unpublished Master's Thesis). Jiangxi Province: Nanchang University.

12. Xiao, X., \& Ding, D. (2018). Research on the development trend of the exhibition industry in the $5 \mathrm{G}$ era. Think Tank Era, 38, 62-62+64.

13. Yu, N. (2017). Intellectual property early warning, response strategies, and enlightenment for Chinese companies participating in German exhibitions (Unpublished Master's Thesis). Hubei Province: Huazhong University of Science and Technology.

14. Zhang, L. (2018). How can overseas exhibitors not be stumbled by intellectual property disputes? China Foreign Trade, 5, 39-41.

15. Zhao, A. L. (2016). The enthusiasm for holding exhibitions outside China has declined. First-tier cities lead to domestic exhibitions. China Foreign Trade, 6, 54-54.

16. Zhao, J. C., \& Xie, J. G. (2017). Overlapping demand structure and China's import trade-An empirical analysis based on similar income distribution. International Trade Issues, 1, 27-42.

(Editors: Yan, Jia-Yi \& Li, De-Lan) 